\title{
An Experimental Study on the Performance of Storage Pulverizing System after Renovation of Importing Hot Air
}

\author{
Guoqing $\mathrm{Han}^{1}$, Hongqi Wei ${ }^{1, *}$, Chang-zheng $\mathrm{He}^{2}$, Ying-hui $\mathrm{Li}^{1}$ \\ ${ }^{1}$ School of Energy and Environment, Southeast University, Nanjing, China \\ ${ }^{2}$ Nanjing Bowo Science and Technology Co. Ltd., Nanjing, China \\ Email: "weihongqi@vip.sina.com
}

Received April, 2013

\begin{abstract}
A thermal power plant of Sinopec has 9 boilers, which generally have problems of high exhaust gas temperature and high flying ash carbon content. In order to improve the adaptability of coals, the stability of coal powder ignition, the burn-off rate of pulverized coals and the boiler efficiency, a series of renovation projects about importing hot air into mill exhauster are proposed. For the sake of verifying the renovation effects, an efficiency performance test is conducted on the renovated $\# 5$ boiler. The test result shows that the boiler heat efficiency has improved by $0.4 \%$ and it operates more safely and reliably after the renovation. At last, this paper recommends an optimized operation mode.
\end{abstract}

Keywords: Storage Pulverizing System; Importing Hot Air Renovation; Performance Test; Operation Optimization

\section{Introduction}

\#1-8 boilers $(8 \times 220 \mathrm{t} / \mathrm{h})$ in a thermal power plant of Sinopec are designed to equip the storage pulverizing systems with exhaust air used as primary air. And coals are pulverized by ball mills. Each boiler is equipped with 2 pulverizing systems. The air temperature of exhauster inlet is about $80-100^{\circ} \mathrm{C}$ when the pulverizing systems use warm air as primary air, and about $65-75^{\circ} \mathrm{C}$ when the exhaust air is used as primary air, which helps the inferior coals to burn steadily and burn off to some extent.

In order to improve the adaptability of coals, the stability of pulverized coals ignition, the burn-off rate of pulverized coals and the boiler efficiency, the plant takes \#5 boiler as a pilot to renovate the pulverizing system with hot air being imported into the exhausters. The $\# 5$ boiler is renovated with 2 hot-air ducts, hot-air dampers, observation points, testing points and so on. The diagram of renovated pulverizing system is shown in Figure 1.

The \#5 boiler is manufactured by Harbin Boiler Factory Co.Ltd. Its type is HG-220/100-10. And it is a natural circulation drum boiler, which was built and operated in August, 1998. The rated evaporation of the boiler is $220 \mathrm{t} / \mathrm{h}$, the rated main-steam pressure is $9.8 \mathrm{MPa}$, the rated main-steam temperature is $540{ }^{\circ} \mathrm{C}$, designed feed-water temperature is $215^{\circ} \mathrm{C}$, designed supply air temperature is $30^{\circ} \mathrm{C}$, designed flue gas temperature is 138 ${ }^{\circ} \mathrm{C}$ and designed Boiler heat efficiency is $91.64 \%$. Bitu-

\footnotetext{
"Corresponding author.
}

minous coal from Shanxi Liujialiang is the designed coal for the boiler. For the pulverizing system, the main equipments' standards and parameters are shown in Table 1.

\section{Testing Contents and Method}

The test is aiming at mastering the influence of the aforementioned renovation on pulverizing system and boiler's performance indexes. Also it will help to ensure the system's safe operation, improve the Boiler heat efficiency and optimize the operation mode.

The test was performed according to the standards of GB10848-88(Performance test code for utility boiler) and DL/T 467-2004(Performance test for pulverizers and pulverizing systems of power station) and with a steam capacity of $200 \mathrm{t} / \mathrm{h}$. During the test pulverized air rate, flame temperatures were measured and samples of powders and ashes were taken, which were analyzed afterward. Besides, the combustion condition inside the furnace was observed and important variables of the boiler system and pulverizing system were recorded.

The schedule of the whole test is as follows:

1) Diagnostic test under the running condition of importing hot air in mill exhauster inlet. Boiler heat efficiency and pulverized air rate were measured with only side a pulverize in operation. The tests were labeled Test 1 and Test 2.

2) Hot air importing tests under various mill exhauster outlet pressures. The tests were performed under three different mill exhauster outlet pressure specifically and 


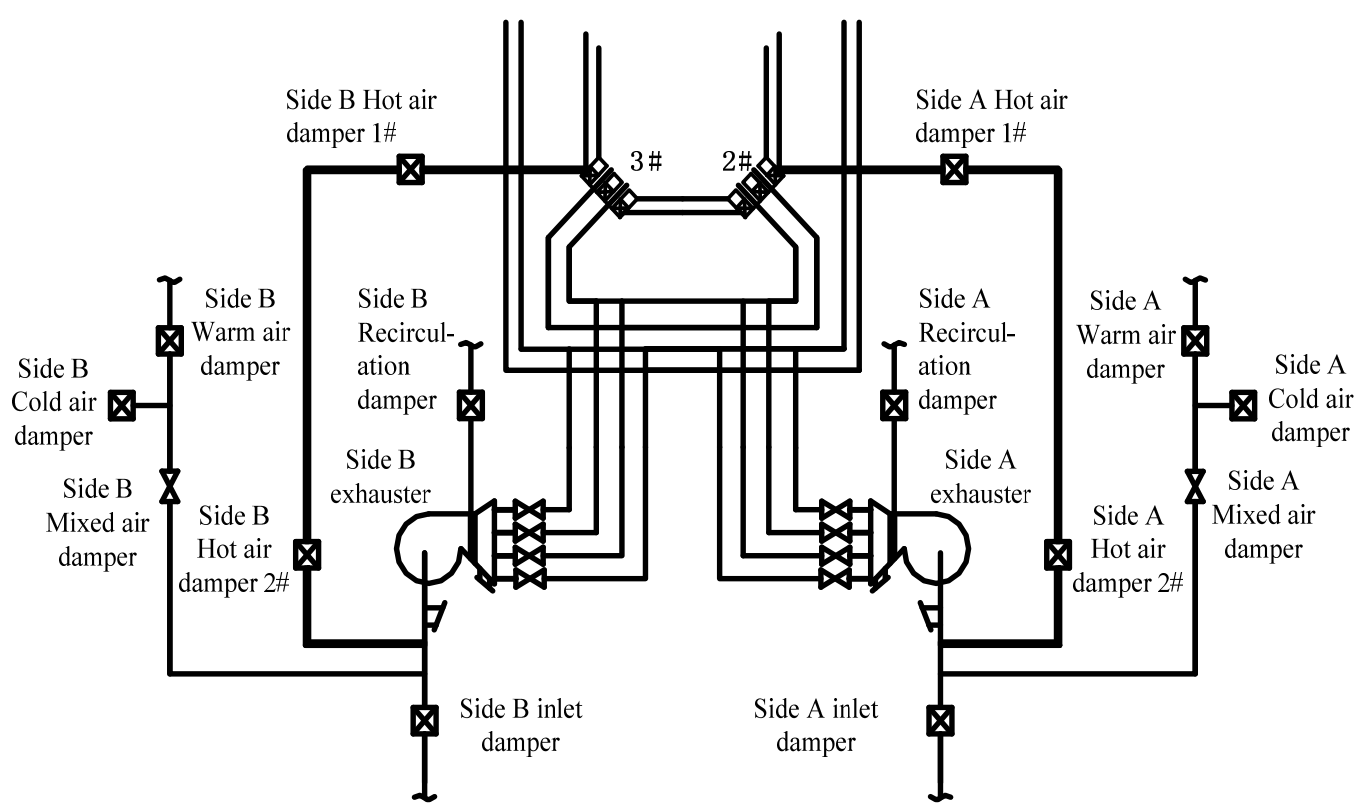

Figure 1. Diagram of renovated pulverizing system installed with hot ducts.

Table 1. Standards and Parameters of main equipments in the pulverizing system.

\begin{tabular}{|c|c|c|c|}
\hline Item & Type or Standard & Parameters & NO. per boiler \\
\hline Coal feeder & ZS-2540 & Standard output $40 \mathrm{t} / \mathrm{h}$ & 2 \\
\hline Pulverizer & DTM290/410 & $\begin{array}{l}\text { Standard output } 14 \mathrm{t} / \mathrm{h} \text {, maximum charge of balls } 30 \mathrm{t} \text {, } \\
\text { Rotating speed } 19.34 \mathrm{r} / \mathrm{min}\end{array}$ & 2 \\
\hline Exhauster & M6-31 No.17D & Air quantity $52700 \mathrm{t} / \mathrm{h}$, total pressure $10523 \mathrm{~Pa}$ & 2 \\
\hline Classifier & HW-CB-II- $\Phi 3400$, centrifugal & Diameter $\Phi 3400 \mathrm{~mm}$ & 2 \\
\hline $\begin{array}{l}\text { Cyclone } \\
\text { collector }\end{array}$ & HW-GXBT-I- $\Phi 2350$, centrifugal & Diameter $\Phi 2350 \mathrm{~mm}$ & 2 \\
\hline
\end{tabular}

were labeled Test 3, Test 4 and Test 5 .

3) Hot air importing test under different ways of operation of the pulverizing system. Boiler heat efficiency and pulverized air rate were measured with side a pulverizer in operation only, side B pulverizer in operation only and both pulverizers in operation specifically. The tests were Test 6 - Test 9.

\section{Results and Analysis}

\subsection{Diagnostic Tests}

The diagnostic tests were both performed with only side a pulbverizer in operation, the tests being Test 1 and Test 2 . In Test 1 the system was running under the condition that there was no hot air importing in the mill exhauster inlet. And in Test 2 there was. In order to guarantee that the system load and air rate are the same for the two tests, mill exhauster outlet pressure was $300 \mathrm{~Pa}$ higher Test 2 than Test 1, the specific hot air rate being $20000 \mathrm{~m}^{3} / \mathrm{h}$; for the sake of operation personnel, mill exhauster outlet pressure was kept 2000-2300 Pa, with which they feel comfortable. Thus the hot air rate of side $\mathrm{B}$ exhauster is $6900 \mathrm{~m}^{3} / \mathrm{h}$, which is much less than that of side A. The relevant test data are listed in Table 2.

It can be known from Table 2 that with mill exhauster outlet pressure fixed to 2000-2300 Pa, the corrected boiler efficiencylcorrected heat loss due to flue gas $\backslash$ heat loss due to mechanical incomplete combustion are specifically $92.44 \% \quad 15.88 \% \quad 10.89 \%$ and $92.71 \% \backslash 5.66 \% \backslash 0.85 \%$. For Test 2 , Boiler heat efficiency is $0.27 \%$ higher, mainly due to reduction in heat loss due to flue gas which is $0.22 \%$. Reduction in mechanically unburned coal heat loss is barely countable, the value being $0.04 \%$. So it can be concluded that measures must be taken to reduce the heat loss due to mechanical incomplete combustion in order to increase 
boiler efficiency.

\subsection{Tests under Various Mill Exhauster Outlet Pressure}

Mill exhauster outlet pressure gets higher as the rate of hot air being imported increases, and so does the mill exhauster outlet air temperature. This can help make ignition of coal powder easier and exhauster gas temperature lower. In order to estimate the influence of mill exhauster outlet pressure on system performance, unburned coal in flying ash and flame temperature were tested under various mill exhauster outlet pressures in Test 3-Test 5 . For these three tests, both pulverizers were in operation with hot air importing only in Test 4 and Test 5 . Side A/B mill exhauster outlet pressures were specifically $2445 \mathrm{~Pa} / 2427 \mathrm{~Pa}, 2634 \mathrm{~Pa} / 2629 \mathrm{~Pa}, 2840 \mathrm{~Pa} / 2940 \mathrm{~Pa}$. Variation of flame temperature and unburned carbon in flying ash and slag are shown in Figure 2 and Figure 3.
In Test 4 , mill exhauster outlet pressure is relatively lower after hot air importing in and result in the decrease of air rate of side B. Although the system was running up to one hour, the pulverizer was popping out powder afterward anyway. It is thought that if mill exhauster outlet pressure maintained regular level when importing in hot air, air rate will drop to an unreasonable low value, which consequently results in the reduction of mill output, 1] and even causes powder popping out and mill blocking. So mill exhauster outlet pressure should be adjusted to a higher than regular level if hot air is to be imported in.

It can be known from Figure 2 that flame temperatures at $10 \mathrm{~m}$ and $14 \mathrm{~m}$ height monotonically increase as the mill exhauster outlet pressure gets higher, which indicates the lowering of the flame center. This will make the coal powder ignition more stable and enable the system to a variety of coals. [2]

Table 2. Data of diagnostic boiler heat efficiency test with hot air imported into exhauster.

\begin{tabular}{|c|c|c|c|}
\hline Variables & Unit & Test 1 & Test 2 \\
\hline Mill operation & / & Side A & Side A \\
\hline Importing hot air or not ${ }^{a}$ & l & No & Yes \\
\hline \multirow{2}{*}{ Exhauster outlet pressure } & $\mathrm{Pa}$ & 1995 & 2301 \\
\hline & $\mathrm{Pa}$ & 2198 & 2254 \\
\hline \multirow{2}{*}{ Air quantity of pulverizing system } & $\mathrm{m}^{3} / \mathrm{h}$ & 42457 & 42077 \\
\hline & $\mathrm{m}^{3} / \mathrm{h}$ & - & - \\
\hline \multirow{2}{*}{ Hot air quantity of exhauster inlet } & $\mathrm{m}^{3} / \mathrm{h}$ & - & 20502 \\
\hline & $\mathrm{m}^{3} / \mathrm{h}$ & - & 6932 \\
\hline Steam flow & $\mathrm{t} / \mathrm{h}$ & 196.2 & 197.1 \\
\hline Testing boiler heat efficiency & $\%$ & 91.90 & 92.16 \\
\hline Corrected boiler heat efficiency & $\%$ & 92.44 & 92.71 \\
\hline Designed boiler efficiency & $\%$ & 91.64 & 91.64 \\
\hline Difference between designed and corrected efficiency & $\%$ & 0.8 & 1.07 \\
\hline Corrected flue gas temperature & ${ }^{\circ} \mathrm{C}$ & 149.4 & 145.3 \\
\hline Excess air coefficient & / & 1.3 & 1.3 \\
\hline Designed excess air coefficient & / & 1.39 & 1.39 \\
\hline Corrected heat loss due to flue gas & $\%$ & 5.88 & 5.66 \\
\hline Content of combustibles in fly ash & $\%$ & 1.3 & 1.5 \\
\hline Content of combustibles in slag & $\%$ & 6.6 & 4.8 \\
\hline Heat loss due to mechanical incomplete combustion & $\%$ & 0.89 & 0.85 \\
\hline Heat loss due to chemical incomplete combustion & $\%$ & 0 & 0 \\
\hline Heat loss due to sensible heat in refuse & $\%$ & 0.25 & 0.24 \\
\hline Heat loss due to radiation & $\%$ & 0.56 & 0.56 \\
\hline
\end{tabular}




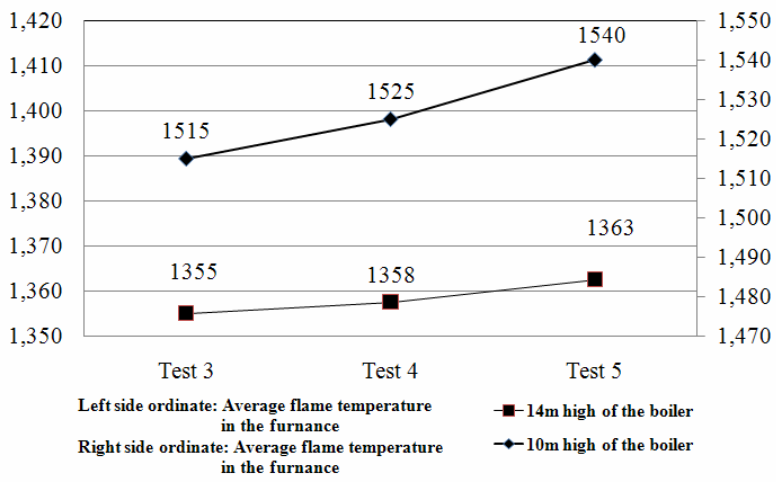

Figure 2. Flame temperature under different mill exhauster outlet pressure $\left({ }^{\circ} \mathrm{C}\right)$.

It can be known from Figure 3 that unburned carbon in both flying ash and slag decrease as the mill exhauster outlet pressure gets higher, causing a reduction in heat loss due to mechanical incomplete combustion up to $0.12 \%$, which is noticeably higher than that during the diagnostic test.

To summarize up, after the renovation of importing hot air into the mill exhauster inlet, the more mill exhauster outlet pressure is, the more hot air will be imported, improving the rigidity of the mixture flow of powder and air, increasing the primary air temperature and making the primary flow rush into the furnace in a better pattern. Besides, the lowering of the combustion center and the increasing of the flame temperature can make the ignition more stable and thus enable the system to a variety of coal with low heat loss due to mechanical incomplete combustion. So it is recommended that mill exhauster outlet pressure should be maintained high (2900-3000 Pa) to get the improvement mentioned above.

\subsection{Hot Air Importing Test under Different Ways of Operation of the Pulverizing System}

Maintaining mill exhauster outlet pressure at 2900$3000 \mathrm{~Pa}$, Boiler heat efficiency and pulverized air volume rate were measured with side $\mathrm{A}$ pulverizer in operation only, side B pulverizer in operation only and both pulverizer in operation specifically. In Test 6 no hot wind was imported in mill exhauster inlet. And hot air was imported to both side pulverizers in Test 7-9.

Test results are shown in Table 3, Table 4, Figure 4 and Figure 5. Influence of hot air in mill exhauster inlet to performance indexes is as follows:

\section{Heat loss due to flue gas}

Corrected exhaust heat loss of Test 7-9 are 5.79\%, $5.83 \%$ and $5.64 \%$ respectively, which are all less than Test 6 when no hot air imported in mill exhauster inlet. Considering the different excess air ratio in Test 9, if the same excess air ratio can be maintained as other Tests,

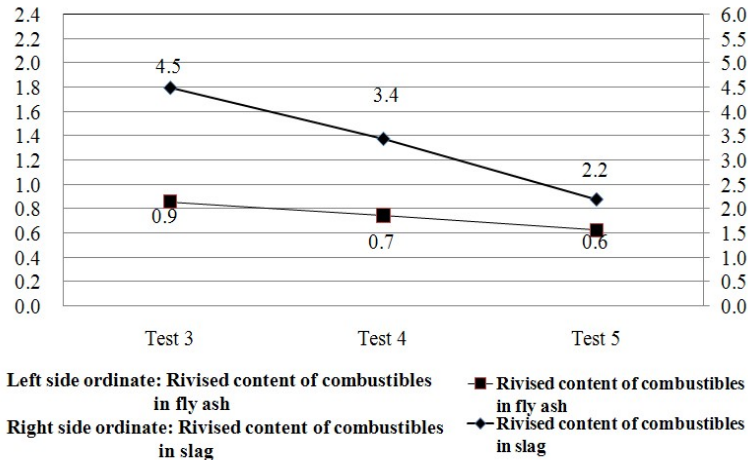

Figure 3. Unburned carbon under different mill exhauster outlet pressure.

heat loss due to flue gas may approximately increase $0.1 \%$ [3] considering influence of both excess air ratio and exhaust gas temperature. So the heat loss due to flue gas should be about $0.3 \%$ in Test 9 . Therefore, when mill exhauster outlet pressure is $2900-3000 \mathrm{~Pa}$, importing hot air to mill exhauster inlet can decrease about $0.24 \%$. Moreover, importing hot air in Pulverize a working method can achieve a comparatively high efficiency.

Heat loss due to mechanical incomplete combustion

In Test 7-9, when hot air was imported in mill exhaust inlet, the $14 \mathrm{~m}$ and $10 \mathrm{~m}$ average flame temperature was increased compared with without hot air. The heat loss due to mechanical incomplete combustions were $0.86 \%$, $0.84 \%$ and $0.83 \%$ respectively in Test $7-9$, lower than in Test 6 and the average reduction is $0.16 \%$. Analysis expressed the decreased heat loss due to mechanical incomplete combustion was related with high mill exhauster outlet pressure and flame temperature in the furnance.

\section{Boiler heat efficiency}

In Test 7-9, mill exhauster outlet temperature is $50^{\circ} \mathrm{C}$ higher than Test 6 , which will lead to earlier ignition of primary air. Meanwhile, importing of primary air and coal powder will lead to more moisture precipitate from coal powder, which increases void fraction of it. Large void fraction makes it easier for excess oxygen to diffuse to internal voids. Thus coal powder can easily ignite and burnout. Corrected Boiler heat efficiency in Test 7-9 is $92.55 \%, 92.53 \%$ and $92.73 \%$, average higher $0.4 \%$ than Test 6 without imported hot air. The result is better than diagnostic tests, mainly due to the positive influence of high mill exhauster outlet pressure and temperature on mechanically unburned carbon.

\section{Mill exhauster motor current}

Normal mill exhauster motor current is $16.5-18.5 \mathrm{~A}$, considering the effect of flue gas recirculation, feed coal quantity, primary wind pressure etc., the average mill exhauster motor current should be about 17.5A. With imported hot air the mill exhauster motor current should 
Table 3. Boiler heat efficiency and losses before and after importing hot air into exhauster.

\begin{tabular}{lccccc}
\hline \multicolumn{1}{c}{ Parameter } & Unit & Test 6 & Test 7 & Test 8 & Test 9 \\
\hline Mill operation & $/$ & Both & Both & Side B & Side A \\
Importing hot air or not ${ }^{\text {a }}$ & & No & Yes & Yes & Yes \\
Steam flow & t/h & 194.6 & 193.6 & 195.2 & 195.2 \\
The testing boiler heat efficiency & $\%$ & 92.92 & 93.34 & 93.44 & 93.62 \\
Revised boiler heat efficiency & $\%$ & 92.17 & 92.55 & 92.53 & 92.73 \\
Revised flue gas temperature & $\%$ & 151.1 & 146.1 & 147.1 & 144.6 \\
Excess air coefficient & $/$ & 1.32 & 1.32 & 1.32 & 1.30 \\
Revised heat loss due to flue gas & $\%$ & 6.02 & 5.79 & 5.83 & 5.64 \\
Content of combustibles in fly ash & $\%$ & 1.54 & 1.56 & 1.29 & 1.09 \\
Content of combustibles in slag & $\%$ & 6.92 & 4.18 & 5.43 & 6.98 \\
Heat loss due to mechanical incomplete combustion & $\%$ & 1.00 & 0.86 & 0.84 & 0.83 \\
Heat loss due to chemical incomplete combustion & $\%$ & 0 & 0 & 0 & 0 \\
Heat loss due to sensible heat in refuse & $\%$ & 0.26 & 0.25 & 0.26 & 0.25 \\
Heat loss due to radiation & $\%$ & 0.57 & 0.57 & 0.56 & 0.56 \\
\hline
\end{tabular}

Table 4. Parameters of pulverizing system before and after importing hot air into exhauster.

\begin{tabular}{|c|c|c|c|c|c|c|}
\hline Parameter & & Unit & Test 6 & Test 7 & Test 8 & Test 9 \\
\hline \multirow{2}{*}{ Mill current } & A & A & 40.9 & 41.1 & - & 41.2 \\
\hline & $\mathrm{B}$ & $\mathrm{A}$ & 48.9 & 50.6 & 51.3 & - \\
\hline \multirow{2}{*}{ Exhauster current } & A & A & 18.1 & 18.3 & 16.1 & 18.1 \\
\hline & $\mathrm{B}$ & A & 18.4 & 18.2 & 18.2 & 16.4 \\
\hline \multirow{2}{*}{ Rotating speed of coal feeder } & A & $\mathrm{rpm}$ & 377 & 366 & - & 331 \\
\hline & B & $\mathrm{rpm}$ & 369 & 360 & 330 & - \\
\hline \multirow{2}{*}{ Opening of exhauster inletdamper } & A & $\%$ & 52 & 58 & 0 & 55 \\
\hline & $\mathrm{B}$ & $\%$ & 65 & 70 & 72 & 0 \\
\hline \multirow{2}{*}{ Opening of recirculation damper } & A & $\%$ & 50 & 100 & 0 & 50 \\
\hline & $\mathrm{B}$ & $\%$ & 50 & 65 & 55 & 0 \\
\hline \multirow{2}{*}{ Opening of exhauster hot air secondary air door } & A & $\%$ & 0 & 100 & 95 & 95 \\
\hline & $\mathrm{B}$ & $\%$ & 0 & 58 & 58 & 62 \\
\hline \multirow{2}{*}{ Negative pressure of classifier outlet } & A & $\mathrm{Pa}$ & -4130 & -3290 & - & -3177 \\
\hline & $\mathrm{B}$ & $\mathrm{Pa}$ & -4110 & -3250 & -3356 & - \\
\hline \multirow{2}{*}{ Exhauster outlet pressure } & A & $\mathrm{Pa}$ & 2550 & 2910 & 2970 & 3030 \\
\hline & $\mathrm{B}$ & $\mathrm{Pa}$ & 2630 & 2920 & 3060 & 2900 \\
\hline \multirow{2}{*}{ Air quantity of pulverizing system } & A & $\mathrm{m}^{3} / \mathrm{h}$ & 51031 & 43742 & - & 43688 \\
\hline & $\mathrm{B}$ & $\mathrm{m}^{3} / \mathrm{h}$ & 50277 & 44010 & 44010 & - \\
\hline \multirow{2}{*}{ Hot air quantity of exhauster inlet } & A & $\mathrm{m}^{3} / \mathrm{h}$ & - & 19949 & 18423 & 18410 \\
\hline & $\mathrm{B}$ & $\mathrm{m}^{3} / \mathrm{h}$ & - & 15175 & 15175 & 16710 \\
\hline \multirow{2}{*}{ Opening of mill warm air damper } & A & $\%$ & 42 & 13 & 0 & 7 \\
\hline & $\mathrm{B}$ & $\%$ & 100 & 62 & 19 & 0 \\
\hline \multirow{2}{*}{ Opening of mill hot air damper } & $\mathrm{A}$ & $\%$ & 70 & 62 & 0 & 67 \\
\hline & $\mathrm{B}$ & $\%$ & 56 & 51 & 62 & 0 \\
\hline \multirow{2}{*}{ Air temperature of exhauster outlet } & A & ${ }^{\circ} \mathrm{C}$ & 76.7 & 122.3 & 146.8 & 120.6 \\
\hline & B & ${ }^{\circ} \mathrm{C}$ & 76.8 & 116.2 & 115.6 & 145.6 \\
\hline \multirow{2}{*}{ Air temperature of exhauster inlet } & A & ${ }^{\circ} \mathrm{C}$ & 155.9 & 321.9 & 328.6 & 326.4 \\
\hline & $\mathrm{B}$ & ${ }^{\circ} \mathrm{C}$ & 132.6 & 320.7 & 327.4 & 327.7 \\
\hline \multirow{2}{*}{ Fineness of pulverized coal $\mathrm{R}_{90}$} & A & $\%$ & 20.8 & 20.8 & - & 20.8 \\
\hline & B & $\%$ & 21.2 & 16.0 & 16.0 & - \\
\hline \multirow{2}{*}{ Fineness of returned coal $\mathrm{R}_{90}$} & A & $\%$ & 70.4 & 60.4 & - & 3.2 \\
\hline & B & $\%$ & 82.8 & 68.4 & 68.4 & - \\
\hline
\end{tabular}




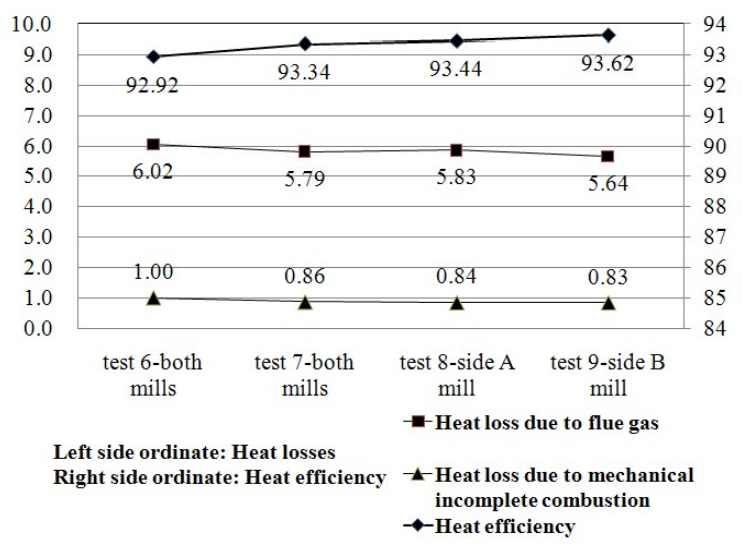

Figure 4. Boiler efficiency and losses under various operation modes (\%).

be $18.5 \mathrm{~A}$ or above. The importing hot air test was performed under the constant pulverizing system output, thus there is no significant change of pulverizer current. When the pulverizer is in operation, imported hot air will increase total air rate. However, due to the initial wind pressure of hot air, mill exhauster motor current only increase slightly.

After the renovation of pulverizing system, maintaining the pulverizer output and mill exhauster outlet pressure at $2900-3000 \mathrm{~Pa}$, hot air increases $0.4 \%$ boiler efficiency. Meanwhile, current of pulverizer and mill exhauster only increases slightly. So the benefit is evident compared with renovation cost.

\section{Recommended Operation Method of Pulverizing System after Importing Hot Air}

Principles for determining the recommended operation method is as follows:

1) System ventilation air rate should be maintained in normal rate, avoiding ventilation output decrease and mill blocking due to low air ventilation rate;

2) Pulverizer output should be maintained the same as it is without hot air imported in;

3) High pressure should be maintained at mill exhauster outlet, thus more hot air can be imported and the Boiler heat efficiency can be higher;

4) Coal powder fineness R90 should be $20-22 \%$;

5) According to $D L / T$ 5121-2000, Technical code for design of thermal power plant air\& flue gas ducts/ raw coal\& pulverized coal piping, flow velocity of recirculation should be above $25 \mathrm{~m} / \mathrm{s}$, lower value may lead to accumulated powder in duct [5].

According to thermal calculation of pulverizing sys$\mathrm{m}[6]$ and experimental result, recommended operation method of pulverizing system after importing hot air are expressed in Table 5.

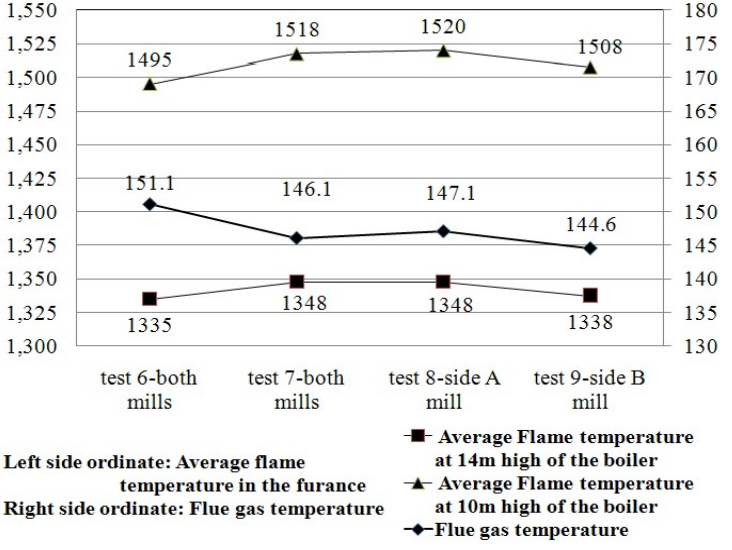

Figure 5. Flame temperature and exhaust flue gas temperature under various operation mode.

Table 5. The recommended optimized mode of operation with hot air imported.

\begin{tabular}{lccc}
\hline \multicolumn{1}{c}{ Operation Parameter } & units & Side A & Side B \\
\hline Exhauster Current & $\mathrm{A}$ & 18.5 & 18.5 \\
Exhauster outlet pressure & $\mathrm{Pa}$ & $\geq 2800$ & $\geq 3000$ \\
Negative pressure of classifier outlet & $\mathrm{Pa}$ & $\geq-3500$ & $\geq-3500$ \\
Opening of recirculation damper & $\%$ & $50-100$ & $40-70$ \\
$\begin{array}{l}\text { Opening of exhauster hot air secondary } \\
\text { air door }\end{array}$ & $\%$ & $90-100$ & $50-70$ \\
\hline
\end{tabular}

Under the condition without imported hot air, when recirculation is not in operation, ventilation rates of two sides of pulverizing system are $43000 \mathrm{~m}^{3} / \mathrm{h}$ and 40000 $5000 \mathrm{~m}^{3} / \mathrm{h}$; when recirculation is in operation, ventilation rates of both sides of pulverizing system are 45000- 0000 $\mathrm{m}^{3} / \mathrm{h}$; according to theoretical calculation, designed value of the milling system ventilation rate should be about $47000 \mathrm{~m}^{3} / \mathrm{h}$. Considering the actual operation conditions, air rate of pulverizing system with imported hot air should be about $46000 \mathrm{~m}^{3} / \mathrm{h}$ to maintain the pulverizing system output. Moreover, the coal powder fineness of both sides is $20 \%-22 \%$.

Mill exhauster outlet pressure and temperature will increase with imported hot air, and the circulation flow velocity can be $50-70 \mathrm{~m} / \mathrm{s}$. Therefore, powder won't accumulate in recirculation duct when recirculation is in operation. However, recirculation air may wear the duct more severely, which should be treated in another renovation.

On account of the primary air quantity changing a little or remaining unchanged, and the hot air imported into exhauster has to return into mills through recirculating ducts, the dampers of recirculating ducts should be wide open when importing hot air. On conditions that the dampers of recirculating ducts are leakproof, it is security to control the air temperature of exhauster outlet only when importing hot air. In a word, it is suggested that the 
air temperature and exhauster outlet pressure should be controlled at $140-150^{\circ} \mathrm{C}$ and $2900 \mathrm{~Pa}$ around on conventional operation.

\section{Conclusions and Suggestions}

- Based on the diagnostic test, when only the mill of side A operates and the outlet pressure of exhauster is holding within the conventional range of 2000-3000Pa, the results show that the corrected Boiler heat efficiency is $92.71 \%$ after importing hot air into the exhauster. It is $0.27 \%$ higher than before. The improvement lies mainly in the heat loss due to flue gas. It decreases by $0.22 \%$, while the decline of heat loss due to mechanical incomplete combustion falls only $0.04 \%$.

- By comparing between the tests of different outlet pressures of exhauster, it is found that more hot air can be imported into the exhauster as the pressure increases. It is beneficial for promoting the rigidity of air flow and the temperature of primary air. Also the organization of pulverized coal and air flow will be strengthened. In addition, the furnace temperature raises and the flame kernel drops with more hot air imported. In a word, it is significant to improve the adaptability of coals, the stability of pulverized coals ignition and the burn-off rate of pulverized coals. Thus it is suggested that when more hot air is imported under the situation of conventional air quantity in the pulverizing system, high outlet pressure of exhauster within 2900-3000 $\mathrm{Pa}$ is appropriate and useful to reduce the heat loss due to mechanical incomplete combustion.

- Under the test conditions of two mills operation altogether, one mill of side A and one mill of side B each running alone, hot air is controlled to import into the exhauster, while the outlet pressure of exhauster maintained within 2900-3000 Pa. After importing hot air, the air temperature of exhauster outlet and the flame temperature in furnace raises significantly. So the combustion condition is better. The test results shows that the corrected heat loss due to flue gas and mechanical incom- plete combustion is less than the operation of two mills without hot air importing. The average decreasing amplitude is $0.24 \%$ and $0.16 \%$ respectively. Also the corrected boiler heat efficiency is $0.4 \%$ higher equally, better than the diagnostic test as well. The main reason is that higher air pressure and temperature of exhauster outlet is beneficial to reduce the heat loss due to mechanical incomplete combustion.

- When the output of mills is stable and the exhauster outlet pressure is maintained within 2900-3000 $\mathrm{Pa}$, there is not much increase in the amount of exhauster current. For this reason, the renovation benefits obviously outweigh the costs.

- In order to achieve the optimized operation after the renovation of the pulverizing system, a recommended mode of operation is presented, which is shown in Table 5.

\section{REFERENCES}

[1] H. X. Jia, "Design and Operation for Coal Milling System," Beijing, China Water Power Press, 1995.

[2] H. X. Ding and J. B. Zhao, "To Solve Combustion Stability Problems Using Exhauster Air/Hot Air Pulverized Coal Feeding System," Electric Power, No. 10, 1995, pp. 41-43.

[3] D. Q. Wei, “Analysis of the Existed Problems before and after the Designed Reform of Hot-draft Coal Powder Feeding System in Laibin Thermal Power Plant A, Guangxi," Guangxi Electric Power, No. 2, 2007, pp. 59-70.

[4] C. Z. Fan, "Principles of Boiler," Beijing, China Water Power Press, 1986.

[5] Y. C. Wang, "Study on the Influence of Air Leakage into Boiler upon Exhaust Gas Temperature and Exhaust Gas Loss," Thermal Power Generation, No. 8, 2007, pp. 19-22.

[6] Z. H. Zhao, A. G. Zhang and W. Y. Wang, "Design and Calculation Method for Thermal Power Plant Pulverizing System," Beijing, China Electric Power Press, 1999. 